\title{
Williams-Beuren Syndrome. Cardiovascular Abnormalities in 20 Patients Diagnosed with Fluorescence in Situ Hybridization
}

\author{
Sofia Mizuho Miura Sugayama, Regina Lúcia Moisés, Jaqueline Wagënfur, Nana Miura Ikari, \\ Kikue Terada Abe, Cláudio Leone, Clóvis Artur Almeida da Silva, \\ Maria de Lourdes Lopes Ferrari Chauffaille, Chong Ae Kim
}

São Paulo, SP - Brazil

\begin{abstract}
Objective - To evaluate the cardiovascular findings and clinical follow-up of patients with Williams-Beuren syndrome.

Methods - We studied 20 patients $(11$ males, mean age at diagnosis: 5.9 years old), assessed for cardiovascular abnormalities with electrocardiography and Doppler echocardiography. Fluorescence in situ hybridization (FISH) was used to confirm the diagnosis of the syndrome.

Results - Elastin gene locus microdeletion was detected in 17 patients ( $85 \%$ ) (positive FISH), and in 3 patients deletion was not detected (negative FISH). Sixteen patients with a positive FISH (94\%) had congenital cardiovascular disease (mean age at diagnosis: 2,3 years old). We observed isolated (2/16) supravalvular aortic stenosis and supravalvular aortic stenosis associated (11/16) with pulmonary artery stenosis (4/11); mitral valve prolapse (3/11); bicuspid aortic valve (3/11); aortic coarctation (2/11), thickened pulmonary valve (2/11); pulmonary valvular stenosis (1/11); supravalvular pulmonary stenosis (1/11); valvular aortic stenosis (1/11); fixed subaortic stenosis (1/11); pulmonary artery stenosis (2/16) associated with pulmonary valvar stenosis (1/2) and with mitral valve prolapse (1/2); and isolated mitral valve prolapse (1/16). Four patients with severe supravalvular aortic stenosis underwent surgery (mean age: 5.7 years old), and 2 patients had normal pressure gradients (mean follow-up: 8.4 years).
\end{abstract}

Conclusion - A detailed cardiac evaluation must be performed in all patients with Williams-Beuren syndrome due to the high frequency of cardiovascular abnormalities.

Key words: Williams-Beuren, elastin, in situ hybridization, supravalvular aortic stenosis

Instituto da Criança do Hospital das Clínicas - FMUSP, Instituto do Coração do Hospital das Clínicas - FMUSP e Laboratório Fleury

Mailing address: Sofia Mizuho Miura Sugayama - Rua João Moura, 2381/51

Cep 05412-004 - São Paulo, SP, Brazil - E-mail: sofiamms@ib.usp.br

Received 9/4/02

Accepted 10/29/02
Williams-Beuren syndrome is a rare condition of deletion of contiguous genes, which is characterized by elfin facies, eye, teeth, cardiovascular, renal, and skeletal abnormalities, mental deficiency, overfriendly personality, and occasionally infantile hypercalcemia ${ }^{1-4}$. Williams et al ${ }^{1}$ in 1961 and Beuren ${ }^{2}$ in 1962 described the syndrome independently. The incidence is estimated at 1:13,700 to $1: 25,000$ live births ${ }^{5,6}$. The occurrence is generally sporadic in most families ${ }^{3,5}$, although reports do exist of a few cases in the same family apparently due to dominant autosomal inheritance ${ }^{7,8}$.

Distinctive facial features described as elfin facies include bitemporal narrowness, periorbital fullness, small upturned nose, full nasal tip, long philtrum, full cheeks, full lips, wide mouth, and small jaw ${ }^{1-4}$. These typical facial features are usually recognizable around 4 months of age and become striking during infancy and childhood ${ }^{3,4}$. Adult patients have dolichocephaly and thick lips ${ }^{3}$.

Clinical diagnostic criteria are available for WilliamsBeuren syndrome ${ }^{3,4}$. Approximately 90 to $95 \%$ of the patients have micro-deletion in the long arm of chromosome 7 (7q11.23), which includes the elastin gene and is detectable by fluorescence in situ hybridization (FISH) ${ }^{9,10}$. This test is useful for diagnostic confirmation, because great clinical variability is present, hindering a diagnosis especially in the first year of life.

Cardiovascular abnormalities occur in almost $80 \%$ of the cases of Williams-Beuren syndrome ${ }^{3,4,11-14}$. Aortic supravalvular stenosis is the most common cardiac anomaly, present in $64 \%$ of patients ${ }^{11}$. Other cardiopathies include pulmonary artery stenosis, aortic hypoplasia, aortic coarctation, mitral valve prolapse, and septal defects ${ }^{11-14}$. In Williams-Beuren syndrome, located and diffuses stenosis of the thoracic and abdominal aorta ${ }^{15,16}$ and the coronary and cerebral arteries ${ }^{17,18}$ may also occur.

The natural history of supravalvular aortic stenosis varies in the affected patients. It may be a progressive lesion characterized by an increase in the pressure gradient of the left ventricle due to hypoplasia of the ascending aorta ${ }^{12}$. 
This abnormality is usually diagnosed in the first 2 years of life; however, it can remain undiagnosed for years, until an increase occurs in the systolic pressure gradient. Symptoms and complications are similar to those of aortic valvar stenosis ${ }^{12}$.

The objective of this study was to analyze the cardiovascular findings and the clinical follow-up of cardiovascular anomalies in 20 patients with Williams-Beuren syndrome.

\section{Methods}

The cohort of this retrospective and prospective study was formed by 20 patients $(11 \mathrm{M}: 9 \mathrm{~F})$ with a clinical diagnosis of Williams-Beuren syndrome followed-up at the Unidade de Genética do ICr-HC-FMUSP(Genetic Unit of Instituto da CriançaHospital das Clínicas-School of Medicine) from 1991 to 2001.

Mean age during clinical diagnosis of Williams-Beuren syndrome was 5.9 years ( 8 months to 10.7 years). The parents were healthy, and all cases were sporadic.

The Williams-Beuren syndrome diagnosis was confirmed with the FISH test. This technique enables the determination of a specific deoxyribonucleic acid (DNA) sequence in a chromosomal band ${ }^{19}$. It consists of the hybridization of a probe fluorescently or radioactively labeled, to identify its complementary segment within a metaphase chromosome. DNA of the metaphase chromosome is denatured in the lamina (for this reason, it is called in situ), and then hybridization is started with a labeled probe. The probe is visualized with fluorescence in the FISH technique or with an X-ray film ${ }^{19}$.

In this study, micro-deletion in the elastin gene was investigated in the interphase and metaphase cells, using VYSIS ${ }^{\circledR}$ LSI Williams Syndrome Region probe (fig. 1), following the Pinkel et al protocol ${ }^{20}$. This is a specific locus probe marked with Spectrum Orange ${ }^{\mathrm{TM}}$ dye, which contains the locus of the elastin gene, the locus of the LIMK1 gene, and the locus of D7S613, a marker of chromosome 7. The control probe marked with Spectrum Green $^{\mathrm{TM}}$ is included in the mixture and corresponds to the loci D7S486 and D7S522

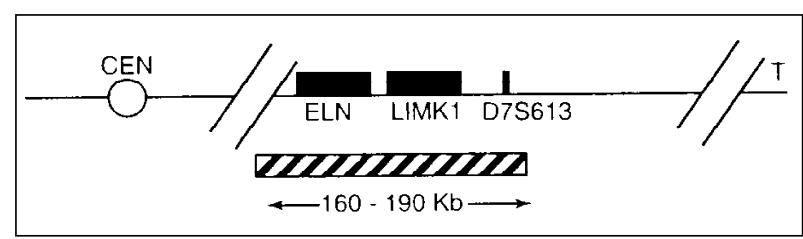

Fig. 1 - Region 7q11.23 and probe VYSIS ${ }^{\circledR}$ LSI Williams Syndrome.

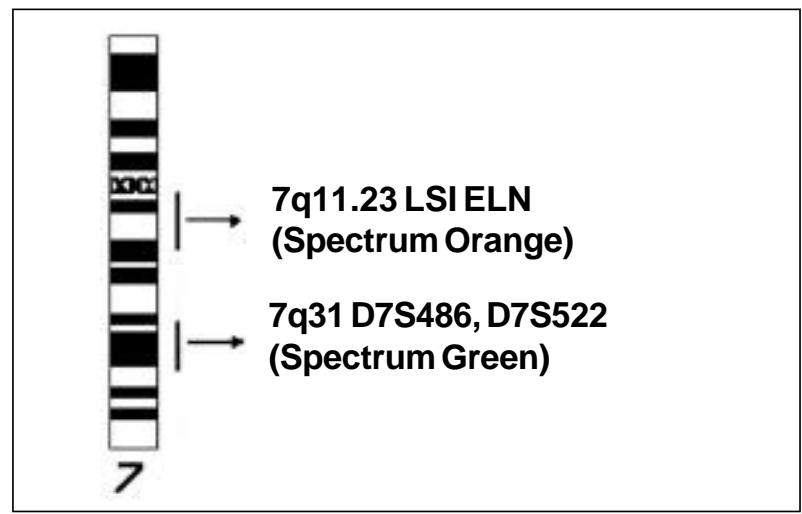

Fig. 2 - Chromosome ideogram 7: regions of probe hybridization.

located in the spectrum 7q31. Figure 2 represents the ideogram of chromosome 7 , showing the hybridization regions of the probe. The presence of only 1 red signal (elastin gene) and 2 fluorescent green signals (markers of chromosome 7) indicates deletion in the elastin gene in 1 chromosome 7, confirming the diagnosis of Williams-Beuren syndrome. In this situation, the patient is considered FISH positive. The patient who has 2 red signals (presence of an elastin gene in both chromosome $7 \mathrm{~s}$ ), and 2 green signals is considered FISH negative (figs. 3a, b).

Cardiac evaluation included a physical examination, electrocardiography, and Doppler echocardiography. Supravalvular aortic stenosis was systematically investigated by the parasternal long axis view in all patients.
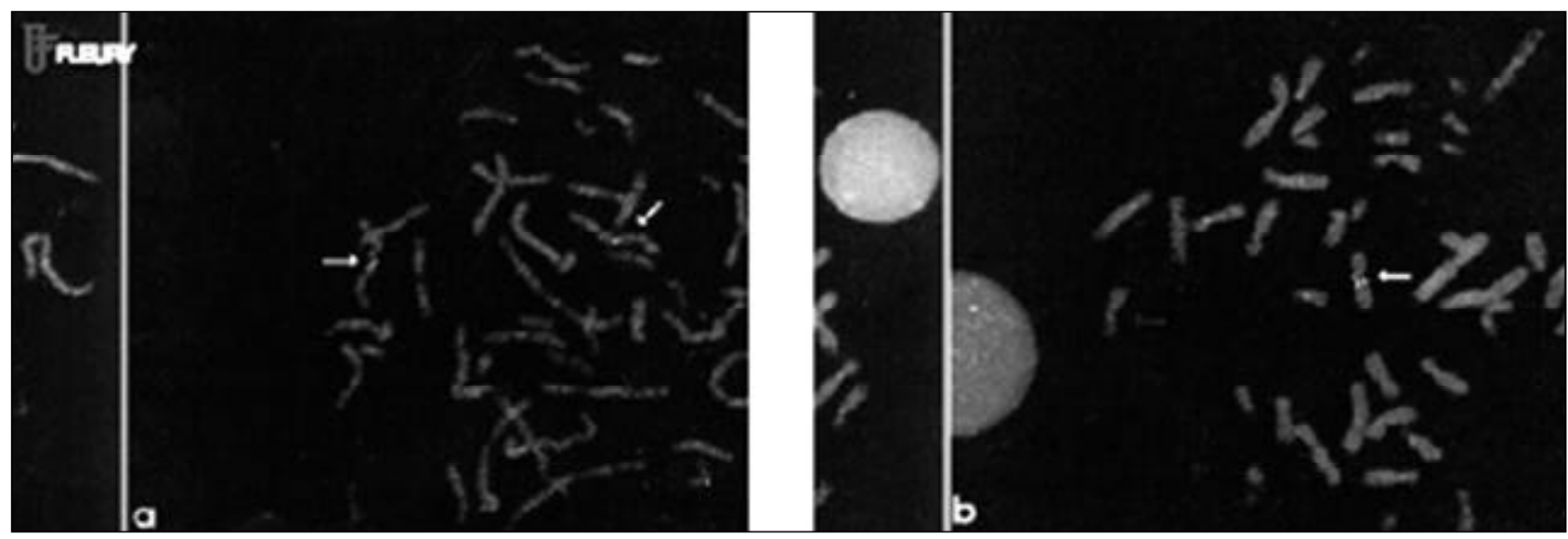

Fig. 3a - Picture of FISH test for Williams-Beuren syndrome demonstrating metaphase with 2 red signals (elastin gene) and 2 green signals (markers chromossome 7), therefore without elastin gene deletion (FISH negative patient); $3 \mathrm{~b}$ - picture of FISH test for Williams-Beuren syndrome demonstrating metaphase with 2 green signals (markers of chromosome 7) and only 1 red signal (elastin gene), however, with deletion of elastin gene (FISH positive patient). 


\section{Results}

All patients had typical facial features (fig. 4). Seventeen patients ( $85 \%$ ) had deletion (FISH positive), and only 3 (15\%) did not have deletion (FISH negative). The 3 patients without deletion had typical facies, mental deficiency, and skeletal abnormalities; however, none of them had congenital cardiovascular disease. Clinical findings of the 20 patients are provided in table I.

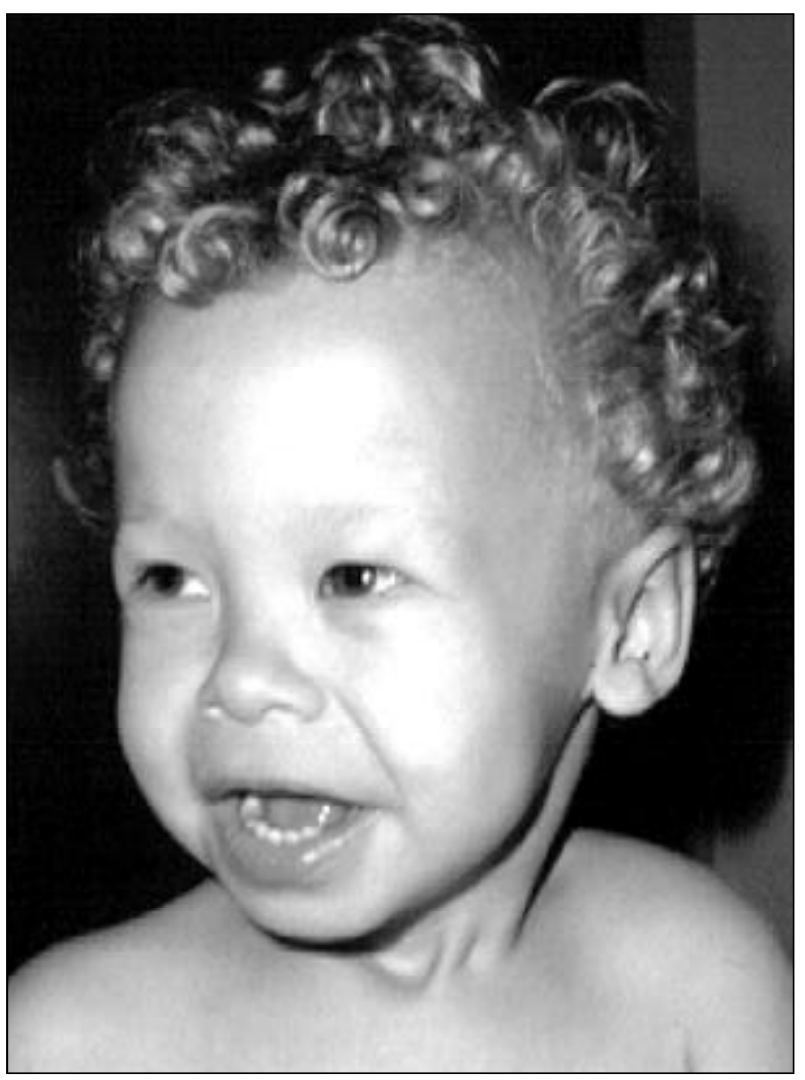

Fig. 4 - A four years old child with typical facial features.

\begin{tabular}{|lcc|}
\hline \multicolumn{3}{|c|}{ Table I - Clinical findings in 20 patients with } \\
Williams-Beuren syndrome
\end{tabular}

Seventeen FISH-positive patients (94\%) had congenital cardiopathy. Cardiac murmur was present in 14/17 $(82 \%)$ of the patients with cardiopathy. Mean age at auscultation was 3 months ( 15 days -4 months). Mean age for diagnosis of heart disease was 2.3 months ( 1 month -7 years). Patients were subdivided according to the type of cardiopathy (tab. II). Mean cardiac follow-up of patients was 7.9 years ( 26 months -11.8 years).

The great majority of patients were asymptomatic. Only 2 patients (cases 1 and 19), with severe supravalvular aortic stenosis had dyspnea and fatigue on great exertion.

Six patients (6/10) with supravalvular aortic stenosis did not need surgery. Two patients (cases 4 and 7 ) had moderate supravalvular aortic stenosis, whose pressure gradients (left ventricle-aorta) were higher than $20 \mathrm{mmHg}$. Case 4 evolved with a mild supravalvular aortic stenosis with a pressure gradient of $20 \mathrm{mmHg}$. Although supravalvular aortic stenosis was severe in case 7, the patient evolved with a decrease in pressure gradient and did not need surgery. Four children with mild supravalvular aortic stenosis (cases 10,11,13, and 15), whose pressure gradients (left ventricle-aorta) were around $20 \mathrm{mmHg}$, evolved with spontaneous regression of stenosis (tab. III).

Four patients with severe supravalvular aortic stenosis (cases 1, 3,19, and 20), whose pressure gradients were higher than $60 \mathrm{mmHg}$, underwent surgery at a mean age of 5.7 years ( 1 year and 7 months -10 years). Surgery was to

\begin{tabular}{|c|c|c|}
\hline \multicolumn{3}{|c|}{$\begin{array}{l}\text { Table II - Cardiac defects in } 20 \text { patients with } \\
\text { Williams-Beuren syndrome }\end{array}$} \\
\hline Heart disease & & $\mathrm{n}(\%)$ \\
\hline \multirow[t]{11}{*}{ SVAS } & Isolated (cases 8 and 10) & $2 / 16(19 \%)$ \\
\hline & Associated & $11 / 16(63 \%)$ \\
\hline & $\begin{array}{l}\text { Pulmonary artery stenosis } \\
\text { (cases } 1,7,13 \text {, and } 15 \text { ) }\end{array}$ & $4 / 11(36 \%)$ \\
\hline & $\begin{array}{l}\text { Bicuspid aortic valve } \\
\text { (cases } 4,13 \text { and 19) }\end{array}$ & $3 / 11(27 \%)$ \\
\hline & $\begin{array}{l}\text { Mitral valve prolapse } \\
\text { (cases } 1,3 \text {, and } 15 \text { ) }\end{array}$ & $3 / 11(27 \%)$ \\
\hline & $\begin{array}{l}\text { Aortic coarctation } \\
\text { (cases } 10 \text { and 20) }\end{array}$ & $2 / 11(18 \%)$ \\
\hline & $\begin{array}{l}\text { Thickened pulmonary valve } \\
\text { (cases } 7 \text { and 11) }\end{array}$ & $2 / 11(18 \%)$ \\
\hline & $\begin{array}{l}\text { Pulmonary valvular stenosis } \\
\text { (case 10) }\end{array}$ & $1 / 11(9 \%)$ \\
\hline & $\begin{array}{l}\text { Supravalvular pulmonary stenosis } \\
\text { (case 15) }\end{array}$ & $1 / 11(9 \%)$ \\
\hline & $\begin{array}{l}\text { Valvar aortic stenosis } \\
\text { (case } 1 \text { ) }\end{array}$ & $1 / 11(9 \%)$ \\
\hline & $\begin{array}{l}\text { Fixed subaortic stenosis } \\
\text { (case 19) }\end{array}$ & $1 / 11(9 \%)$ \\
\hline \multirow[t]{4}{*}{ PAS } & Associated (cases 2, and 5) & $2 / 16(13 \%)$ \\
\hline & $\begin{array}{l}\text { Valvular pulmonary stenosis } \\
\text { (case 5) }\end{array}$ & $1 / 2(50 \%)$ \\
\hline & $\begin{array}{l}\text { Mitral valve prolapse } \\
\text { (case 2) }\end{array}$ & $1 / 2(50 \%)$ \\
\hline & Isolated (case 18) & $1 / 16(13 \%)$ \\
\hline \multicolumn{3}{|c|}{ Mitral valve prolapse } \\
\hline Total & & $16 / 16(100 \%)$ \\
\hline
\end{tabular}


enlarge the aorta with a bovine pericardial graft at the site of stenosis. All patients evolved well in the postoperative period with a reduction in the pressure gradient. Mean followup after surgery in 3 patients (cases 1, 3, and 19) was 5.7 years. The pressure gradient was normal after surgery in 2 patients (cases 1 and 3 ) in a mean follow-up of 8.4 years, without restenosis.

Two patients had aortic coarctation associated with supravalvular aortic stenosis (cases 10 and 20) with pressure gradients of 22 and $37 \mathrm{mmHg}$ and with mild hemodynamic repercussions. Both patients were asymptomatic.

Table IV presents the mean pressure gradients and the follow-up period of patients with pulmonary aortic stenosis associated with supravalvular aortic stenosis $(6 / 16=38 \%)$.

Pulmonary artery branch stenosis and valvular pulmonary stenosis were diagnosed in case 5 at 9 months. Hemodynamic study, at 2 years, demonstrated multiple pulmonary artery stenoses, with stenosis in the origin and periphery of the right hypoplastic branch and the left branch the left ventricle and aorta were normal. Surgery was not indicated because the patient was compensated and the lesions were difficult to reach. Pressure gradient decreased spontaneously to $28 \mathrm{mmHg}$ in a 6.6-year follow-up. Pulmonary artery stenosis in case 1 was corrected at 10 years, together with supravalvular aortic stenosis surgery. In the 5 remaining patients (cases 2, 5, 7, 13, and 15) stenosis resolved spontaneously even in cases 7 and 13 whose pulmonary artery stenosis was moderate.

\begin{tabular}{|cccc|}
\hline \multicolumn{4}{|c|}{ Table III - Supravalvular aortic stenosis follow-up } \\
\hline Cases & $\begin{array}{c}\text { Initial } \\
\text { Gradient }\end{array}$ & $\begin{array}{c}\text { Final } \\
\text { Gradient }\end{array}$ & $\begin{array}{c}\text { Follow-up } \\
\text { Period }\end{array}$ \\
\hline 1 & $>70$ & 0 & 11.8 years \\
3 & $>70$ & 0 & 9.3 years \\
4 & 45 & 20 & 7.1 years \\
7 & 75 & 60 & 13.5 years \\
8 & 55 & 51 & 4.7 years \\
10 & $\ldots$ & 25 & 6.8 years \\
11 & 15 & 0 & 8.4 years \\
12 & 6 & $\ldots$ & $\ldots$ \\
13 & 23 & 17 & 6.3 years \\
14 & $\ldots$ & 30 & 13.3 years \\
15 & 19.5 & 0 & 9.6 years \\
19 & $>70$ & 14 & 2.2 years \\
20 & 94 & 0 & 9.3 years \\
Mean & $>49.4$ & 18.1 & 7.9 years \\
\hline
\end{tabular}

\begin{tabular}{|cccc|}
\hline \multicolumn{4}{|c|}{ Table IV - Pulmonary artery follow-up } \\
\hline Cases & $\begin{array}{c}\text { Initial } \\
\text { gradient }\end{array}$ & $\begin{array}{c}\text { Final } \\
\text { gradient }\end{array}$ & $\begin{array}{c}\text { Follow-up } \\
\text { period }\end{array}$ \\
\hline 1 & - & 0 & 11.8 years \\
2 & 26 & 0 & 10.3 years \\
5 & 92 & 28 & 6.9 years \\
7 & 65 & 0 & 13.5 years \\
13 & 59 & 0 & 6.3 years \\
15 & 24 & 0 & 9.6 years \\
Mean & 44.3 & 4.7 & 9.7 years \\
\hline
\end{tabular}

\section{Discussion}

In the present study, heart disease was diagnosed in $81 \%$ of the patients, similar to that reported in the literature with incidences of 75 to $80 \%{ }^{11-13}$. Tables $\mathrm{V}$ and VI summarize the types of heart diseases and their frequency in the present sample and in the main studies of literature.

Supravalvular aortic stenosis frequency $(65 \%=13 / 20)$ in the present study was similar to that observed in the literature ${ }^{12,13}$. Pulmonary artery stenosis (38\%) was the second heart disease associated with supravalvular aortic stenosis, as in the studies in the literature (tab. V). Doppler echocardiography is the examination of choice to detect supravalvular aortic stenosis and other heart diseases ${ }^{11-13}$.

Bicuspid aortic valve was seen in 19\% of the patients from the present sample, whereas Hallidie-Smith and Karas ${ }^{21}$ observed this anomaly in $12 \%$ of their study patients with Williams-Beuren syndrome. However, the frequency of mitral valve prolapse (19\%) in the present study was similar to that reported in the study. Other studies reported a lower incidence of mitral valve prolapse, ranging from $1 \%^{12}$ to $2 \%{ }^{13}$. In the present sample, the frequency of aortic coarctation (13\%) was greater than that reported in the literature, which ranges from $2 \%{ }^{6,13}$ to $7 \%^{14}$. Frequencies of pulmonary valvular stenosis (1/16), supravalvular aortic stenosis (1/16), and aortic stenosis (1/16) in the present study were similar to those reported in the literature ${ }^{4-6}$.

Fixed subaortic stenosis without hemodynamic repercussion was diagnosed in one of our patients. This abnormality was described in the literature by Narin et al ${ }^{22}$ in an 8year-old boy with Williams-Beuren syndrome.

In the present study, 1 patient (case 14) had bilateral renal artery stenosis in addition to supravalvular aortic stenosis and mitral valve prolapse. In the Zalzstein et al study $^{13}$, of $8 / 11$ of the patients with supravalvular aortic stenosis and pulmonary artery stenosis, 1 patient had splenic artery stenosis and another patient had abdominal aortic stenosis. Arteriopathy in Williams-Beuren syndrome is generalized and may involve any artery of the body due to elastin deletions ${ }^{9,10}$.

\begin{tabular}{|lccc|}
\hline \multicolumn{4}{|c|}{$\begin{array}{c}\text { Table V - Supravalvular aortic stenosis and pulmonary artery } \\
\text { frequency in patients with Williams-Beuren syndrome }\end{array}$} \\
\hline Author & N & SVAS & PAS \\
\hline Beuren et al $^{2}$ & 23 & $23(100 \%)$ & $23(100 \%)$ \\
Jones \& Smith $^{4}$ & 19 & $7(37 \%)$ & $3(16 \%)$ \\
Grimm \& Wesselhoeft $^{5}$ & 79 & $79(100 \%)$ & $65(82 \%)$ \\
Martin et al $^{6}$ & 41 & $16(39 \%)$ & $11(27 \%)$ \\
Hallidie-Smith \& Karas $^{21}$ & 61 & $61(100 \%)$ & - \\
Morris et al $^{3}$ & 59 & $40(68 \%)$ & - \\
Zalzstein et al $^{13}$ & 49 & $39 / 49(80 \%)$ & $19(39 \%)$ \\
Kececioglu et al $^{12}$ & 104 & $85 / 104(82 \%)$ & $80 / 93(86 \%)$ \\
Pankau et al $_{\text {not published) }}$ & 124 & $96(77 \%)$ & $60(48 \%)$ \\
Wessel et al $^{14}$ & & & $49(83 \%)$ \\
Present study & 59 & $57(97 \%)$ & $6 / 16(38 \%)$ \\
\hline *Modified from Wessel et al & $(1994)$. & & \\
\hline
\end{tabular}




\begin{tabular}{|c|c|c|c|c|c|c|c|}
\hline Author(s) & $\mathrm{N}$ & SVAS & PAS & AS & ACo & HAo & Others \\
\hline Beuren $\mathrm{AJ}^{2}$ & 23 & - & - & - & - & $7(30 \%)$ & - \\
\hline Jones \& Smith ${ }^{4}$ & 19 & - & $5(26 \%)$ & $1(5 \%)$ & - & $3(16 \%)$ & 2IAC, 2IVC \\
\hline Grimm \& Wesselhoeft ${ }^{5}$ & 79 & $2(3 \%)$ & $4(5 \%)$ & - & $4(5 \%)$ & $55(70 \%)$ & 1IAC, 2IVC, 2ACP \\
\hline Martin et al ${ }^{6}$ & 41 & - & $1(2 \%)$ & - & $1(2 \%)$ & - & 3IVC \\
\hline Hallidie-Smith \& Karas ${ }^{21}$ & 61 & - & - & - & - & $1(2 \%)$ & $\begin{array}{l}\text { Mitral valve prolapse } \\
\text { IIAC, 1IVC }(15 \%)\end{array}$ \\
\hline Morris et $\mathrm{al}^{3}$ & 59 & $10(17 \%)$ & $6(10 \%)$ & - & $3(5 \%)$ & - & - \\
\hline Zalzstein et al ${ }^{13}$ & 49 & - & - & - & $2(4 \%)$ & - & 1Mitral valve prolapse $(2 \%)$ \\
\hline Kececioglu et al ${ }^{12}$ & 104 & - & - & - & $5 / 104(5 \%)$ & & $\begin{array}{l}\text { 1ACP, } 1 \text { Mitral valve } \\
\text { prolapse, } 1 \mathrm{CIV}\end{array}$ \\
\hline $\begin{array}{l}\text { Pankau et al } \\
\text { (not published) }\end{array}$ & 124 & $1(1 \%)$ & $1(1 \%)$ & $2(2 \%)$ & $8(6 \%)$ & $36(29 \%)$ & 2IAC, 3IVC, 1TF, 1IAA \\
\hline Wessel et al ${ }^{14}$ & 59 & - & - & - & $4(7 \%)$ & $24(41 \%)$ & \\
\hline Present study & $20(13 \%)$ & $2 / 16(6 \%)$ & $1 / 16(6 \%)$ & $1 / 16(13 \%)$ & $2 / 16(19 \%)$ & $-(16 \%)$ & $\begin{array}{l}\text { 3Mitral valve prolapse } \\
2 \mathrm{MH}\end{array}$ \\
\hline
\end{tabular}

Great variability occurred in the pressure gradient of patients with supravalvular aortic stenosis in the present study. These data were similar to those in the literature in which pressure gradient ranged from 0 to $110 \mathrm{mmHg}$ in the study of Kececioglu et al ${ }^{12}$, and $105 \mathrm{mmHg}$ in the study of Wessel et al ${ }^{14}$.

In the present study, the patients with mild supravalvular aortic stenosis, whose pressure gradients were $\leq 20 \mathrm{mmHg}$, evolved with a reduction in the pressure gradient as reported in the literature. In the Wessel et al study ${ }^{14}$, a mean pressure gradient of $9 \mathrm{mmHg}$ remained unchanged in 32/45 of the patients with mild supravalvular aortic stenosis during infancy, in a mean 13-year follow-up.

Zalzstein et al ${ }^{13}$ subdivided the patients with supravalvular aortic stenosis into those with isolated supravalvular aortic stenosis and those with supravalvular aortic stenosis associated with pulmonary artery stenosis. The first was present in 28/49 (57\%) patients; in 17/28 (61\%) of them, no worsening in stenosis occurred during a 6.3-year followup. However, 7/24 (29\%) of the patients with initial pressure gradients higher than $30 \mathrm{mmHg}$ evolved with an increase in pressure gradient and required corrective surgery of supravalvular aortic stenosis. Eleven patients $(11 / 49=22 \%)$ had supravalvular aortic stenosis and pulmonary artery stenosis; 6 of them evolved with worsening of supravalvular aortic stenosis, whereas pulmonary artery stenosis either remained unchanged or even decreased. Five of them (5/6) underwent supravalvular aortic stenosis surgery.

In the Kececioglu et al study ${ }^{12}$, supravalvular aortic stenosis was classified into 3 groups according to the pressure gradient: 1) mild supravalvular aortic stenosis (0-30 $\mathrm{mmHg}$ ) - 54/85 patients; 2) moderate supravalvular aortic stenosis (30-50 $\mathrm{mmHg})-12 / 85$ patients, and 3 ) severe supravalvular aortic stenosis $(50-110 \mathrm{mmHg})-19 / 85$ patients. The natural course of supravalvular aortic stenosis was assessed in 21 patients through hemodynamic study 11 years after the first catheterization, on average. The pressure gra- dient in the aorta increased in 11 patients, and in 4 of them, the increase was $\geq 50 \mathrm{mmHg}$; the pressure gradient remained unchanged in $9 / 85(11 \%)$, and decreased to $45 \mathrm{mmHg}$ in $1 / 85$ patients.

The frequency of patients undergoing supravalvular aortic stenosis surgery in the present study was similar to that reported in the literature (tab. VII). In the Kececioglu et al study ${ }^{12}$, the mean postoperative follow-up was 8.6 years in 29/85 patients with Williams-Beuren syndrome, undergoing surgery to correct supravalvular aortic stenosis. Surgery resulted in a $30 \mathrm{mmHg}$ decrease in the aortic pressure gradient in 22 patients.

We observed in the present sample that the severity of pulmonary artery stenosis decreased in childhood and adolescence as reported in the literature. Of the 6 patients with pulmonary artery stenosis, only 1 underwent surgical correction. The 5 remaining patients evolved with a spontaneous reduction in the initial mean pressure gradient from $44.3 \mathrm{mmHg}$ to $4.7 \mathrm{mmHg}$ in a 9.7-year follow-up.

In the Zalzstein et al study ${ }^{13}, 8 / 49$ of the patients had isolated pulmonary stenosis, and 11/49 patients had pulmonary artery stenosis associated with supravalvular aortic stenosis. In $5 / 8$ of the patients, no change in stenosis severity occurred, and 1 patient underwent surgery at 12 years of age. In 6/11 patients with pulmonary aortic stenosis associated with supravalvular aortic stenosis, pulmonary stenosis improved spontaneously in all cases.

Pulmonary artery stenosis was diagnosed in $80 / 93$ pa-

\begin{tabular}{|c|c|c|}
\hline \multicolumn{3}{|c|}{$\begin{array}{c}\text { Table VII - Corrective surgery frequency in supravalvular aortic } \\
\text { stenosis (SVAS) }\end{array}$} \\
\hline Author & SVAS & Mean age \\
\hline Zalzstein et al ${ }^{13}$ & $12 / 39(31 \%)$ & - \\
\hline Kececioglu et al ${ }^{12}$ & $29 / 85(34 \%)$ & 11 years $(2.5-25)$ \\
\hline Wessel et al ${ }^{14}$ & $17 / 57(32 \%)$ & - \\
\hline Present study & $4 / 13(31 \%)$ & 5.7 years $(19 \mathrm{~m}-10 \mathrm{y})$ \\
\hline
\end{tabular}


tients with Williams-Beuren syndrome in the Kececioglu et al study ${ }^{12}$. The pressure gradient in the right ventricle was increased in 55/80 patients, and it was mild or moderate in 75 patients, and severe in 5 patients. We observed a significant reduction in the pressure gradient of 14 patients.

In the Wessel et al study ${ }^{14}$, the pressure gradient assessed on hemodynamic study decreased spontaneously from a mean of 23 to $9.5 \mathrm{mmHg}$ in 23/49 patients with pulmonary artery stenosis over 14 years. In adolescent and adults aged $>33$ years, the pressure gradient were lower than $20 \mathrm{mmHg}$ in $22 / 23$ patients.

In the present study, only 2 patients had aortic coarctation of mild hemodynamic repercussion. In the Kececioglu et al study ${ }^{12}, 5 \%(5 / 104)$ had aortic coarctation, and all patients underwent surgical correction. In the Wessel et al sample ${ }^{14}$, aortic coarctation was also severe in $4 / 59$ patients (7\%) who had it, 2 of them required surgery.

Cardiovascular anomalies caused by elastin deficiency are the most significant cause of morbidity and mortality in Williams-Beuren syndrome ${ }^{11-23}$. Surgical correction of severe supravalvular aortic stenosis must be indicated, once the patients with significant pressure gradients are at risk of sudden death ${ }^{12,22}$. Kececioglu et al ${ }^{12}$ estimated that the risk of sudden death was 3\% in a series of 104 patients with Williams-Beuren syndrome followed-up for 30 years. Pathologic findings observed by Bird et al. ${ }^{23}$ in 10 patients with Williams-Beuren syndrome who died suddenly were coronary artery stenosis and acute myocardial ischemia in 5 patients.

Immediate surgical results in patients with WilliamsBeuren syndrome demonstrate low mortality and the longterm prospective studies revealed that most patients underwent surgery evolved well with stable pressure gradients and without restenosis.

An accurate cardiovascular evaluation is recommended when diagnosis is performed in all patients with Williams-Beuren syndrome, including electrocardiography and Doppler echocardiography. If the initial evaluation does not detect any cardiac abnormalities, a yearly follow-up should be performed to detect and prevent future complications.

\section{References}

1. Williams JCP, Barratt-Boyes BG, Lowe JB. Supravalvular aortic stenosis. Circulation 1961; 21: 1311-8.

2. Beuren AJ. Supravalvular aortic stenosis: a complex syndrome with and without mental retardation. Birth Defects: OAS VIII 1962; 5: 45-56.

3. Morris CA, Demsey AS, Leonard CO, Dilts C, Blackborn. Natural history of Williams syndrome: physical characteristics. J Pediatr 1988; 113: 318-26.

4. Jones, KL, Smith, DW. The Williams elfin facies syndrome. JPediatr 1975; 86: 718-23.

5. Grimm $T$, Wesselhoeft $H$. The genetic aspects of Williams-Beuren syndrome and the isolated form of the supravalvular aortic stenosis; investigation of 128 families. Z Kardiol 1980; 69: 168-72.

6. Martin NDT, Snodgrass GJAI, Cohen RD. Idiopathic infantile hypercalcemia: a continuing enigma. Arch Dis Child 1984; 59: 605-13.

7. Cortada X, Taysi K, Hartman AF. Familial Williams syndrome. Clin Genet 1980; 18: 173-6.

8. White RA, Preus M, Watters GV, Fraser FC. Familial occurrence of the Williams syndrome. J Pediatr 1977; 91: 614-6.

9. Lowery MC, Morris CA, Ewart A, et al. Strong correlation of elastin deletions, detected by FISH, with Williams syndrome: evaluation of 235 patients. Am J Hum Genet 1995; 57: 49-53.

10. Nickerson E, Greenberg F, Keating MT, McCaskill C, Shaffer LG. Deletions of the elastin gene at 7q11.23 occur in $90 \%$ of patients with Williams syndrome. Am J Hum Genet 1995; 56: 1156-61.

11. Conway JR, Noonan J, Marion, RW, Steeg CN. Myocardial infarction leading to sudden death in the Williams syndrome: report of three cases. J Pediatr 1990; 117: 593-5.

12. Kececioglu D, Kotthoff S, Vogt J. Williams-Beurens syndrome: a 30-year followup of natural and postoperative course. Eur Heart J 1993; 458-64.
13. Zalzstein E, Moes CAF, Musewe NN, Freedom RM. Spectrum of cardiovascular anomalies in Williams-Beuren syndrome. Pediatr Cardiol 1991; 12: 219-23.

14. Wessel A, Motz R, Pankau R, Bursch, JH. Arterial hypertension and blood pressure profile in patients with Williams-Beuren syndrome. Z Kardiol 1997; 86: 251-7.

15. Sumboonnanonda A, Robinson BL, Gedroyc MWM, Saxton HM, Reidy JF, Haycock GB. Middle aortic syndrome: clinical and radiological findings. Arch Dis Child 1992; 67: 501-5.

16. Panayiotopoulos YP, Tyrrel MR, Koffman G, Reidy JF, Haycock GB, Taylor PR. Mid-aortic syndrome presenting in childhood. Br J Surg 1996; 83: 235-40.

17. Kawai M, Nishikawa T, Tanaka $M$, et al. An autopsied case of Williams syndrome complicated by moyamoya disease. Acta Paediatr Jpn 1993; 35: 63-7.

18. Soper R, Chaloupka JC, Fayad PB, et al. Ischemic stroke and intracranial multifocal cerebral arteriopathy in Williams syndrome. J Pediatr 1995; 126: 945-8.

19. Stumm M, Tönnies H, Wieacker PF. Molecular cytogeneic techniques for the diagnosis of chromosomal abnormalities in childhood disease. Eur J Pediatr 1999; 158: 531-6.

20. Pinkel D, Straume T, Gray JW. Cytogenetic analysis using quantitative, high sensitivity fluorescence hybridization. Proc Natl Sci USA 1986; 83: 2934-8.

21. Hallidie-Smith KA, Karas S. Cardiac anomalies in Williams-Beuren syndrome. Arch Dis Child 1988; 63: 809-13.

22. Narin N, Özyürek R, Bakiler AR, Parlar A, Arcasoy M, Köprübasi F. Williams syndrome and subaortic stenosis. Clin Genet 1993; 44: 223.

23. Bird LM, Billman GF, Lacro RV, et al. Sudden death in Williams syndrome: report of tem cases. J Pediatr 1996; 129: 926-31. 